\title{
ESPAÇO DE ENUNCIAÇÃO, CENA ENUNCIATIVA, DESIGNAÇÁO
}

\section{SPACE OF ENUNCIATION; ENUNCIATIVE SCENE, DESIGNATION}

\author{
Eduardo Guimarães \\ Universidade Estadual de Campinas, Campinas, SP, Brasil
}

\begin{abstract}
Resumo: Neste artigo, Eduardo Guimarães reflete sobre as relaçôes entre o espaço de enunciação e a cena enunciativa, e sobre a constituiçăo da designação no acontecimento enunciativo. A análise de um conjunto de textos que tratam de açôes da colonização portuguesa no Brasil quinhentista nos permite ver operar um conjunto de conceitos e categorias da Semântica do Acontecimento, como político, reescrituração, domínio semântico de determinação, entre outros, e nos permite conhecer aspectos da história do Brasil, nesta reflexão que tem como foco as línguas, os nomes e o seu funcionamento na enunciação.
\end{abstract}

Palavras-chave: Espaço de enunciação; cena enunciativa; história do Brasil; línguas do Brasil.

Abstract: In this article, Eduardo Guimarães reflects upon the relationship between the space of enunciation and the enunciative scene, and upon the constitution of the designation in the enunciative event. The analysis of a set of texts describing actions of Portuguese colonization in sixteenth-century Brazil allows us to follow the operation of a set of concepts and categories of the Semantics of the Event, such as those of politics, rewriting, semantic domain of determination, among others, and puts us in contact with some new knowledge about aspects the history of Brazil, in a reflection that focuses on languages, names and their functioning in enunciation.

Key-words: Space of enunciation; enunciative scene; history of Brazil; Brazilian languages.

$\mathrm{O}$ conceito de espaço de enunciação tem, para a semântica da enunciação, tal como a pratico, um lugar central e decisivo. A partir dele, foime possível pensar o funcionamento das línguas na sua relação constitutiva com seus falantes, o que de imediato coloca o político como próprio deste funcionamento ${ }^{1}$.

Para refletir um pouco sobre os contornos deste conceito, vou me dedicar neste texto a refletir sobre as relações entre o espaço de enunciação e a cena enunciativa e sobre a constituição da designação no acontecimento enunciativo. Dada a posiçáo que tomamos a propósito da análise semântica, precisamos considerar acontecimentos de enunciação, ou seja, textos que se produzem pelo funcionamento da língua nos espaços de enunciação. Para a

\footnotetext{
${ }^{1}$ Ver mais à frente como tomo esta concepção do político, em "Sobre o Espaço de Enunciação".
} 
presente reflexão, vou tomar um conjunto de textos de um momento muito particular da história do Brasil, o século XVI. Vou me concentrar na primeira parte desse século. São textos sobre as ações da colonização portuguesa.

De saída, um aspecto importante na abordagem de um corpus, para minha posição, é produzir recortes ${ }^{2}$ no corpus que tragam elementos decisivos para a análise, segundo seus objetivos. O que os enunciados devem apresentar para serem tomados na análise é este caráter decisivo para o andamento da reflexão.

Segundo essa posição, vamos tomar como motivo de reflexão os recortes que seguem.

(1) Martim Afonso de Souza do Conselho de El-Rei Nosso Senhor, governador destas terras do brasil, etc. [...] Eu hei por bem de lhe dar e doar as terras de Taquararira com a serra de Taperovira que está na banda donde nasce o sol com águas vertentes com o rio Jarabatyba o qual rio e terras estão defronte da ilha de S. Vicente donde chamam Gohayó a qual terra subirá... ${ }^{3}$. (Carta de doação de sesmaria feita por Martim Afonso de Souza a Pero de Góes em 1533, in MARQUES, M. A., s/d, tomo II, p. 265 e ss.).

(2) Por onde não parece razão, que lhe neguemos este nome (Província de Santa Cruz), nem que nos esqueçamos dele tâo indevidamente por outro que the deu o vulgo mal considerado, depois que o pau da tinta começou de pau-brasil vir a estes Reinos. Ao qual chamaram brasil por ser vermelho e ter semelhança de brasa, e daqui ficou a terra com este nome de Brasil (GÂNDAVO, 1576, p. 66) ${ }^{4}$.

(3) Estes aimorés são mais alvos e de maior estatura que os outros índios da terra, com a língua dos quais não tem a destes nenhuma semelhança nem parentesco... Estes alarves têm feito muito dano nestas capitanias depois que desceram a esta costa, e mortos alguns portugueses e escravos, porque são mui bárbaros, e toda a gente da terra lhes é odiosa (GÂNDAVO, 1576, p. $140)^{5}$.

\footnotetext{
${ }^{2} \mathrm{O}$ recorte é uma categoria descritiva formulada no interior da Análise de Discurso [e tal como a utilizo desde Texto e Argumentação (GUIMARÃES, 1987)]: “o recorte é uma unidade discursiva. Por unidade discursiva entendemos fragmentos correlacionados de linguagem-esituação. Assim, um recorte é um fragmento da situação discursiva" (ORLANDI, 1983, p. 14). Ao apropriar esta noção ao domínio dos estudos enunciativos, disse em Guimarães (2011) que o recorte "é um fragmento do acontecimento da enunciação". Guardando a caracterização de Orlandi, não se trata simplesmente de uma sequência, mas de formas linguísticas que aparecem como correlacionadas em virtude de terem uma mesma relação com o acontecimento, independentemente da posição na sequência (GUIMARÃES, 2008).

${ }^{3}$ Grifos nossos.

${ }^{4}$ Grifos nossos.

${ }^{5}$ Grifos nossos.
} 


\section{Sobre o Espaço de Enunciaçáo}

Retomemos, para começar, o conceito de espaço de enunciação tal como o defini:

Os espaços de enunciação são espaços de funcionamento de línguas, que se dividem, redividem, se misturam, desfazem, transformam por uma disputa incessante. São espaços "habitados" por falantes, ou seja, por sujeitos divididos por seus direitos ao dizer e aos modos de dizer. (GUIMARÁES, 2002, p. 18).

Nessa medida, os espaços de enunciação são espaços que distribuem desigualmente as línguas para seus falantes, e assim redividem o sensível, ao identificarem os indivíduos ao serem tomados pelas línguas. $\mathrm{O}$ espaço de enunciação é um espaço político, no sentido em que venho considerando o que seja o político.

Considero o político no sentido em que o utilizei esse termo em Guimarães (2002). Este modo de tratar o político vem da formulação que lhe dá Orlandi'. O político é definido como "relação de confronto" (ORLANDI, 1990, p. 35). Essa concepção recebe mais especificaçóes pela consideraçáo do silêncio como fundamento do sentido. Segundo ela "o silêncio fundador não recorta: ele significa em si. E é ele, afinal, que determina a política do silêncio: é porque significa em si que o 'não-dizer' faz sentido e faz sentido determinado. É o silêncio fundador, portanto, que sustenta o princípio de que a linguagem é política" (ORLANDI, 1990, p. $51)^{7}$. Por outro lado, considero a formulaçáo de Rancière (1995) que define a política como "desentendimento". A análise de Rancière me possibilitou um modo de apresentar a questão formulando-a nos termos de uma abordagem enunciativa. E faço isso mantendo o sentido do político como confronto. Foi nessa perspectiva que disse (GUIMARÁES, 2002, p. 12), que o político é a contradição que instala o conflito no centro do dizer. No que vai abaixo, apresentei essa relação de conflito, numa formulaçáo enunciativa, como uma afirmação de pertencimento:

Ele (o político) se constitui pela contradiçáo entre a normatividade das instituiçôes sociais que organizam desigualmente o real e a afirmaçâo de pertencimento dos não incluídos. O político é a afirmação da igualdade, do pertencimento do povo ao povo, em conflito com a divisão desigual do real,

\footnotetext{
${ }^{6}$ Aspecto que a referida teórica desenvolveu em muitos textos posteriores.

${ }^{7}$ Esta posição, como sabemos, vai se desenvolver e levar a muitas consequências a partir de Orlandi (1992).
} 
para redividi-lo, para refazê-lo incessantemente em nome do pertencimento de todos no todos. (GUIMARÁES, 2002, p. 17).

Dada essa configuraçáo do espaço de enunciaçáo, é preciso dizer que sentido dou ao termo falantes. Segundo considerei em trabalho anterior:

Os falantes não são os indivíduos, as pessoas que falam esta ou aquela língua. Os falantes são estas pessoas enquanto determinadas pelas línguas que falam. Neste sentido falantes não são as pessoas na atividade físico-fisiólogica, ou psíquica, de falar. São sujeitos da língua enquanto constituídos por este espaço de línguas e falantes que chamo espaço de enunciação. (GUIMARÃES, 2002, p. 18).

Busquemos agora a configuração do espaço de enunciação das línguas do Brasil no início da colonização. Em outro lugar (GUIMARÁES, 2005), apresentei uma breve história da configuração do espaço de enunciação no Brasil, considerando os relatos de historiadores e linguistas. Segundo o que disse, desde a introdução da Língua Portuguesa no Brasil, a partir de 1500, a configuraçáo do espaço de enunciação brasileiro pode ser considerada em quatro períodos. O primeiro se caracterizaria pela relação, na colônia portuguesa, do português com as línguas indígenas, com as línguas gerais e com o holandês. Nessa configuração do espaço de enunciação, as línguas gerais eram línguas francas, e o português, língua oficial do Estado português (o final do período seria marcado pela saída dos holandeses, e assim da língua holandesa, em 1654). O segundo período, com a saída do holandês, se caracterizaria pela relação entre o português (língua oficial), as línguas indígenas, as línguas gerais e as línguas africanas dos escravos. O português, que já era língua oficial, passa a ser a língua mais falada (tal período termina em 1808 com a chegada da família real ao Brasil). O terceiro período se caracterizaria pela predominância da língua oficial que se instala como "língua de todos" e assim regula a distribuição das línguas no espaço de enunciação. É desse momento a criação da imprensa oficial no Brasil (então sede do império) e da Biblioteca Nacional (vai até 1826). O quarto período se inicia com um movimento claro de consideração do português como língua nacional do Brasil, então independente. Assim o português passa a ser náo só a língua oficial e mais falada, mas a língua nacional, marcando um movimento que leva a uma nova relação. A língua nacional e a oficial (sobrepostas) passam a funcionar sobre o modo de presença das línguas indígenas, das línguas africanas e de línguas de imigrantes que começam a vir para o Brasil. Uma reflexão mais específica pode melhor precisar esta caracterização. Para esta reflexão, vou me circunscrever numa temporalidade 
tomada na relação com o Diario da Navegaçáo da Armada que foi à Terra do Brasil em 1530 - Sob a Capitania-mor de Martim Affonso de Souza, de Pero Lopes de Souza (1530-1532). Como se verá, isso tomará um período menor que o apresentado na síntese histórica acima.

Quanto ao procedimento de análise, vou tomar como centro da reflexão, para caracterizar um espaço de enunciação específico, a configuração própria de acontecimentos de enunciação. $\mathrm{O}$ que é necessário fazer neste caso é considerar fatos ${ }^{8}$ que apontam para a categoria do falante de um lado e fatos de língua de outro (sabendo que os fatos de língua são constituídos por uma história de enunciaçóes).

Para a análise de acontecimentos de enunciaçáo, podemos analisar a cena enunciativa, relaçóes de reescrituração e articulação, etc. E a partir disso considerar como certos fatos remetem às línguas, para além do que dizem no acontecimento.

Vamos partir de dois acontecimentos de enunciação colocados a partir dos recortes (1) e (2), que apresentamos anteriormente. Eles envolvem duas nomeaçôes: uma da ilha de Sáo Vicente (colocada pelo recorte (1) de um texto de 1532); e outra do Brasil (colocada pelo recorte (2) de um texto de 1576). E este modo de tomar a questáo se sustenta em que o texto do Diario de 1532 não se refere ao Brasil por Província de Santa Cruz, nem por Brasil, mas por terras do brasil. Nessa expressão, está presente brasil, o pau da tinta chamado, segundo o recorte (2), de pau-brasil, ou simplesmente brasil.

Em (1) e em (2), há a apresentação de duas nomeaçóes feitas em Língua Portuguesa, sem nenhuma referência a nenhuma outra língua. A língua que se apresenta é a língua na qual os textos estão escritos (a língua oficial do império português). No entanto, nos dois casos, as enunciaçôes sobre um nome oficial, São Vicente em (1), e Provincia de Santa Cruz em (2), fazem significar uma outra enunciação de um outro nome, Gohayó em (1) e brasil e Brasil em (2).

No caso de (1), podemos dizer que o acontecimento se refere à ilha de São Vicente com esse nome e mostra a existência de um outro nome - Gohayó. Um nome em outra língua. E isso se explicita na medida em que o falante de português, enquanto locutor no acontecimento, apresenta a enunciaçấo deste nome, Gohayó, como uma enunciação que é excluída, excluindo-se assim também o próprio nome. Exclui-se o nome, excluem-se os falantes da língua.

No caso de (2), o acontecimento de enunciação sustenta a necessidade

\footnotetext{
${ }^{8}$ Os fatos para uma teoria são a apropriação, pelo método, de dados que interessam ao cientista.
} 
de manter um nome - Província de Santa Cruz - em contraposição a outro nome. Sobre este nome, Brasil, do qual se relata a existência, relata-se também quem nomeia por este nome, "o vulgo".

Há outras vozes nessas duas enunciaçôes que falam em outra língua (outras línguas). E, se há outras enunciaçôes em outras línguas, há também outros falantes. E que falante está em cada caso? O índio em (1) e os envolvidos ("o vulgo") no comércio de pau brasil em (2). Como sabemos, e se verá a seguir, brasil era o nome dado à madeira por todos os envolvidos no comércio da madeira: índios, franceses, portugueses, etc.

Ou seja, as enunciações oficiais envolvendo nomes próprios decisivos nesta história (o da ilha de São Vicente e depois da primeira vila, e o da colônia referida) significam outros falantes (outras línguas) e outros nomes (em outras línguas). Em outras palavras, mesmo que esses textos não sejam o documento direto da existência de outras línguas, eles as significam, de uma maneira muito particular. Estes textos, pela análise da significação, deixam ver como as línguas, mesmo que postas no lugar da inexistência ${ }^{9}$, significam sua existência.

O que colocamos por essas duas sequências é que, mesmo que isto não seja dito, está-se enunciando, de algum modo, a existência de enunciaçóes em outras línguas que nomeiam lugares na colônia. Ao mesmo tempo, as sequências anteriores significam, de modos diferentes, é verdade, a recusa desses nomes, portanto dessas enunciaçóes e dessas outras línguas.

Isso nos permite dizer que esses dois acontecimentos tornam possível afirmar que esses acontecimentos de linguagem se dáo num espaço de enunciação em que estão o português e outras línguas, entre elas, línguas indígenas. E não só isso. $\mathrm{O}$ espaço de enunciação distribui essas línguas desigualmente, como se pode ver pelo modo de presença da língua indígena e da enunciação do nome Gohayó. Assim, ser falante de português é ser falante de uma língua legítima; ser falante da língua indígena é ser falante de uma língua excluída, que não pode nomear lugares. Os acontecimentos dos dois recortes (1) e (2) significam essa interdição. Por outro lado, é interessante observar como essa interdição é contraditória. Basta retornar ao recorte (1) para nele encontrar nomes como Taquararira, Taperovira e Jarabatyba, que aparecem normalmente como palavras da Língua Portuguesa, que já eram, naquele momento, mas que são palavras que se incorporam ao português vindas de línguas indígenas. São enunciaçôes que irrompem na enunciação do falante da Língua portuguesa, no momento mesmo em que uma enunciação na língua indígena é significada como

${ }^{9}$ Caracterizei essa “inexistência” em Guimarães (2014). 
existindo e, ao mesmo tempo, é excluída (a de Gohayó). Ou seja, instalase uma distribuição política das línguas para os falantes, mas os falantes determinados pelas línguas não-contadas continuam a falar nessas línguas e elas afetam a língua dominante politicamente no espaço de enunciação.

E a presença de nomes e de enunciaçóes, num acontecimento em Língua Portuguesa, mostra que os falantes estão, nesse espaço de enunciaçáo, afetados por essas línguas. Poderia representar isso como segue:

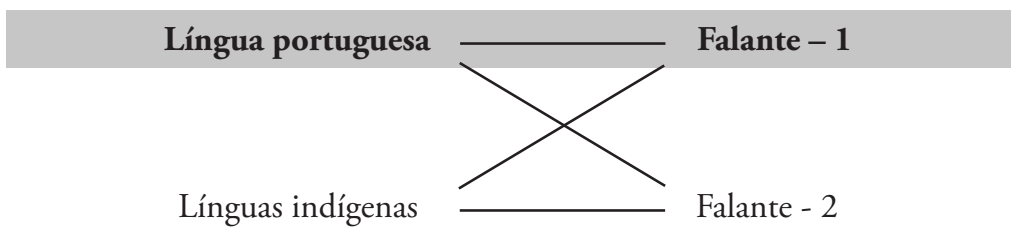

No diagrama apresentado, as linhas contínuas horizontais relacionam as línguas e os falantes que as falam, e as transversais relacionam as línguas e os falantes que podem ou não as falar. A relação em destaque (negrito) significa sua posição dominante no espaço de enunciação, ou seja, o espaço de enunciação, naquelas condiçóes, colocava uma relação entre português e seus falantes, de um lado, e línguas indígenas e seus falantes, de outro. Estando a primeira relação exposta à segunda e vice-versa (tomando o espaço como um todo), esses falantes não eram falantes da outra língua. A diferença entre o que se realça ou não significa o limite entre o dominante e o interditado; fronteira, por sinal, aberta às relaçôes mútuas, exatamente por seu caráter político. O diagrama também significa que, mesmo que um falante, o falante-2, por exemplo, não fale a Língua Portuguesa, ele está determinado em relação a ela no espaço de enunciação considerado e viceversa.

Entáo, podemos inicialmente dizer que a relação no espaço de enunciação era significada pelo sentido da dominação da Língua Portuguesa nesse espaço. E isso não significa que as línguas entraram em contato, o que produziu certos efeitos. É mais que isso. O que mostramos aqui é que há, efetivamente, nas enunciaçóes que analisamos, um embate enunciativo que traz diretamente a substituição de uma nomeação numa língua por outra, agora na língua dominante.

O espaço de enunciaçáo tal como apresentado anteriormente, pelos textos que tomamos para a análise, dizem respeito à primeira metade do 
século XVI, mas falta considerar ainda um aspecto. Tomemos para isso o recorte (2):

(2) Por onde não parece razão, que lhe neguemos este nome (Província de Santa Cruz), nem que nos esqueçamos dele tấo indevidamente por outro que the deu o vulgo mal considerado, depois que o pau da tinta começou de pau-brasil vir a estes Reinos. Ao qual chamaram brasil por ser vermelho e ter semelhança de brasa, e daqui ficou a terra com este nome de Brasil (GÂNDAVO, 1576, p. 66) ${ }^{10}$.

Aqui encontramos o relato de uma enunciação. O Locutor de (2) nos diz que a Província de Santa Cruz tem outro nome, Brasil. E esse outro nome é atribuído a uma nomeação "que lhe deu o vulgo", ou seja, trata-se de uma nomeação que passa por uma história de enunciaçóes cujo lugar social de locutor é "o vulgo"; sendo assim, é uma nomeaçáo que não se dá do lugar de um locutor-governante ${ }^{11}$. Mas o mais importante aqui é que o relato dessa enunciação leva a considerar uma relação entre índios e franceses na costa do Brasil, como já está dito no Diario de Pero Lopez de Souza.

Pero Lopez de Souza, logo depois da chegada da Armada de Martim Afonso de Souza à costa do Brasil, apresenta o combate entre a Armada portuguesa e embarcaçóes francesas. A narrativa conta a perseguição e luta entre a Armada e os franceses, ou seja, conta-se uma ação de hostilidade entre portugueses e franceses, que extraíam brasil. Nesse embate, a Armada apreende as naus francesas e o pau-brasil que transportavam (SOUZA, 1531, p. 10-12). Esse relato de hostilidade, sem que disso se tenha falado, coloca-nos diante da relação da Língua Portuguesa e da Língua Francesa na costa das chamadas, à época, terras do Brasil, expressão presente no próprio Diario de Pero Lopes de Souza. Encontramos no relato da viagem, no registro do dia três de fevereiro de 1531: "Este dia vieram de terra, a nado, às naos índios a perguntar-nos se queriamos brasil” (SOUZA, 1531, p. 13).

$E$, na sequência desse relato, encontramos:

Sabado pela menháa quatro de febreiro mandou o Campitam J. a Heitor de Sousa, Capitam da nao Sam Miguel que fosse a terra com o batel e com mercadorias, ver se poderia trazer algua agua, de que tinhamos muita necessidade: e se tornou sem trazer agua, por lha nam querer dar a gente da terra (p. 13).

\footnotetext{
${ }^{10}$ Grifamos.

${ }^{11}$ Mais à frente falaremos da configuração da cena enunciativa.
} 
Tal como disse em Guimarães (2013), o relato nos apresenta dois acontecimentos de enunciação: no primeiro os portugueses recebem um oferecimento (o narrador não nos diz a resposta dada, o que implicita no texto um modo de negação, e o envolvimento dos índios na extração de pau brasil, portanto uma relaçáo deles com os franceses); no segundo os portugueses solicitam alguma coisa, como parte de uma troca (mercadorias por água) e recebem uma negativa. $\mathrm{O}$ que significa uma hostilidade entre a gente da terra e os portugueses.

Desse modo, podemos ver que há, no espaço de enunciação considerado, outras línguas e outras relaçóes: o francês e as línguas indígenas e as relaçóes dessas línguas com o português. Isso também vai na direção de se considerar a diversidade das línguas indígenas. Vê-se que, no caso anteriormente abordado, há índios, com sua língua, que mantêm relação próxima com os franceses e sua língua. Podemos então observar um confronto de línguas que envolve o francês. No entanto, não se pode notar, pelos textos tomados para a análise, nenhuma relaçáo cotidiana envolvida, ou seja, podemos avaliar, não levando em conta aqui a diversidade das línguas indígenas, que as relações seriam:

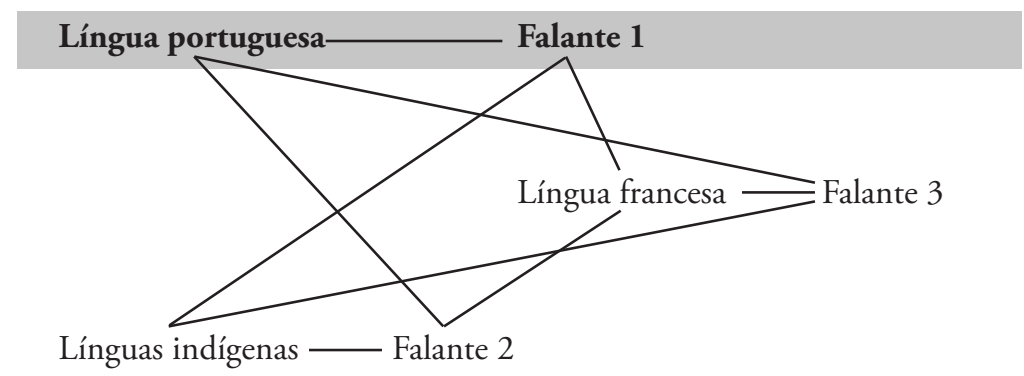

Observa-se que as relaçóes, no início da colonizaçáo, colocam em contatos novos, num novo espaço de enunciação, duas línguas do espaço de enunciação europeu com outro conjunto de línguas, de um novo espaço, constituindo assim um novo espaço de enunciação. Nele, o primeiro embate está no contato, em outros termos, entre essas línguas europeias com outras línguas que não tinham, até entáo, relação alguma com o português e o francês.

Do ponto de vista da caracterização do espaço de enunciação específico, observamos que, mesmo que tomado globalmente no Brasil de então, o holandês não faz parte desse momento do início da colonização. 
Desse modo, podemos considerar que a primeira configuração do espaço de enunciação nas terras do brasil é algo que precede o que consideramos como primeiro momento na síntese colocada acima. A consideração dessa primeira configuração do espaço de enunciação pode ter grande interesse para a melhor compreensão da história dos espaços de enunciação no Brasil.

A caracterização do embate político, como se vê, coloca-o como próprio da análise do fato, e não como algo simplesmente externo que se correlaciona com o linguístico. Náo se trata de considerar o embate do desentendimento próprio do político num domínio que depois se projeta no linguístico. O embate é linguístico, é enunciativo, na perspectiva que adoto.

\section{Cena Enunciativa: um Embate Particular}

Comecemos retomando o modo como definimos e caracterizamos a cena enunciativa. Tal como já disse, a cena enunciativa "se caracteriza por constituir modos específicos de acesso à palavra dadas as relaçôes entre as figuras da enunciação e as formas lingüísticas". Nessa medida, as cenas enunciativas "são especificaçôes locais nos espaços de enunciação" e são um espaço particularizado de agenciamento do falante em locutor que distribui os lugares de enunciação no acontecimento. Os lugares enunciativos

\footnotetext{
[...] são configuraçôes específicas do agenciamento enunciativo para "aquele que fala" e "aquele para quem se fala". $\mathrm{Na}$ cena enunciativa "aquele que fala" ou "aquele para quem se fala" não são pessoas mas uma configuraçấo do agenciamento enunciativo. São lugares constituídos pelos dizeres e não pessoas donas de seu dizer. Assim estudá-la é necessariamente considerar o próprio modo de constituição destes lugares pelo funcionamento da língua. (GUIMARÁES, 2002, p. 23).
}

Para avançar, vamos analisar a cena enunciativa do recorte (1). Essa análise já a fiz em Guimarães (2013). Vou retomá-la nos termos do nosso interesse presente.

(1) Martim Afonso de Souza [...]. Faço saber [...] que havendo respeito em como Pedro de Góes, [...], servio muito bem Sua Alteza nestas partes [...]. Eu hei por bem de lhe dar e doar as terras de Taquararira com a serra de Taperovira que está na banda donde nasce o sol com águas vertentes com o rio Jarabatyba o qual rio e terras estão defronte da ilha de $\mathrm{S}$. Vicente donde chamam Gohayó $\boldsymbol{o}^{12}[\ldots]$.

\footnotetext{
${ }^{12}$ Grifos nossos.
} 
Podemos considerar que o acontecimento do recorte (1) agencia o falante de português em Locutor ${ }^{13}$. Ao agenciá-lo em Locutor, agencia-o enquanto um lugar social de locutor ${ }^{14}$, mais especificamente, enquanto um locutor-governante que se refere à ilha de São Vicente. E diz isso como um enunciador ${ }^{15}$ universal (Euniv), significando que esse é o nome da ilha, para todos. Nesse mesmo acontecimento, há um outro lugar social de locutor que diz um outro nome da ilha, em outra língua. É um locutor-índio que aparece na voz de um enunciador genérico (Egco). Assim a enunciaçáo do nome na língua indígena é relegada por uma renomeação assumida pelo locutor-governante. A voz do enunciador genérico é diluída e preterida pela voz universal que refere em Língua Portuguesa. E essa preterição, tal como já disse em Guimarães (2013), instala-se definitivamente na história sobre o Brasil e na própria história do Brasil, mesmo que, num texto como o do recorte (1), o locutor-governante, como se pode ver, refira-se a vários lugares por nomes indígenas desses lugares. E esses nomes já aparecem, no recorte transcrito, como incorporados ao português, diferentemente de Gohayó. Gohayó é uma palavra enunciada como da língua indígena. O locutorgovernante relata a enunciação do locutor-índio. $\mathrm{O}$ nome Gohayó e sua enunciação não são do acontecimento que nomeia a ilha de São Vicente, é ele um nome de uma outra temporalidade de sentidos. Assim, mesmo que a relação das línguas esteja operando sobre o português, a nomeação da ilha funciona como um apagamento dessa relaçáo. Isso nos permite observar o quanto a cena enunciativa se dá como uma configuração no espaço de enunciação. $\mathrm{Na}$ cena enunciativa, o falante é agenciado em Locutor, e mais que isso, em um lugar social de locutor. E esse agenciamento do acontecimento produz sentido. E o que determina o falante, no espaço de enunciação, significa, de algum modo, na cena enunciativa.

Essa cena instala o correlato de L, o Alcutário (AL), e instala também o alocutário-x, enquanto lugar social, correlato ao lugar social de locutor. Isso, no caso de (1), se produz pela performatividade específica dessa enunciação, o que nos leva a um alocutário-súdito (correlato do locutor-governante). Podemos apresentar a cena como segue:

\footnotetext{
${ }^{13}$ A figura da cena enunciativa que se apresenta como origem do que se diz (GUIMARÃES, 2002).

${ }^{14}$ O que chamo (GUIMARÃES, 2002, p. 24) também de locutor-x, ou simplesmente 1-x. O x é a variável que a análise deve preencher na caracterização deste lugar social de locutor, no presente caso, governante.

${ }^{15} \mathrm{O}$ enunciador é o lugar de dizer em que também se divide o Locutor, além de sua divisão em lugar social de locutor (GUIMARÃES, 2002, p. 25).
} 
$L-$ l-gov.: $\left\{\begin{array}{l}\text { l-indio: } \\ \text { Egco }- \text { Esta ilha se chama Gohayó } \\ \text { Euniv - eu hei por bem }[. . .] \text { S.Vicente a qual serra subirá }[\ldots . .]\end{array}\right\}$ al-súdito $-A L$

Ao mesmo tempo, a referência à ilha pelo nome São Vicente faz significar, na história da nomeação oficial da ilha pela Coroa portuguesa, o memorável do acontecimento de sua nomeaçáo (que o acontecimento toma como o passado que nele significa), que traz toda a história enunciativa envolvendo o nome de São Vicente (santo da Igreja Católica). O nome da ilha de São Vicente significa a posse de um lugar, mas, mais que isso, significa a história de um país (Portugal) constituído na luta cristã (contra os árabes, os mulçumanos) na península ibérica. Em contrapartida, o nome do santo, na história enunciativa do nome da ilha, significa a recusa ao nome, à língua e aos falantes que nomearam o lugar de Gohayó e transpóe para a colônia a história portuguesa. Isso faz eco com a presença de alarves para predicar certos índios, como se verá à frente.

Assim o nome São Vicente ${ }^{16}$ para a ilha, na terra do brasil, é uma enunciação que traz um memorável litigioso. No acontecimento de nomeaçáo da ilha, podemos observar um litígio em que uma história enunciativa é negada no acontecimento que nomeia, ou seja, que renomeia.

Por outro lado, o litígio no qual significa a nomeação Gohayó tem, no presente do acontecimento, o efeito de significar o agenciamento do locutor na relação da coroa portuguesa com a terra do brasil e não mais com a história portuguesa de nomeaçôes de seu território.

\section{Designação: um Nome de Índio}

Retomemos o que consideramos como designação de um nome ${ }^{17}$. A designação é o sentido de um nome que estabelece a relação desse nome com as coisas tomadas como existentes, mas esta relação não é referencial. Trata-se de um processo pelo qual os nomes identificam ${ }^{18}$ aquilo sobre o que falam. A linguagem, nessa medida, produz uma 'partilha do real' ${ }^{19}$. A designação identifica o existente (físico ou não) de algum modo, e essa é a

\footnotetext{
${ }^{16}$ Ver uma análise específica sobre este nome em Guimarães (2013).

${ }^{17}$ Tal como consideramos em Guimarães (2002).

${ }^{18}$ No sentido dado por Rancière (1994).

${ }^{19}$ No sentido que esta expressão tem para Rancière (1995).
} 
relação que tem com ele, a qual, inclusive, possibilita que se faça referência a coisas particulares em situaçóes particulares.

Em cenas enunciativas como a que analisamos, ou em outras como as que aparecem nos recortes (2) e (3), podemos observar o funcionamento da designaçáo do nome indio enquanto um nome que nomeia falantes das línguas do Brasil.

Se tomamos, por exemplo, na História da Província Santa Cruz, de onde retiramos o recorte (3), o modo como se determina o sentido de indio, pode-se mostrar que a designação desse termo é determinada (predicada semanticamente) por gentio e bárbaro. É interessante analisar que outras determinaçôes estão em jogo nesse caso e nos demais. Se tomamos o recorte

(3) Estes aimorés são mais alvos e de maior estatura que os outros índios da terra, com a língua dos quais não tem a destes nenhuma semelhança nem parentesco... Estes alarves têm feito muito dano nestas capitanias depois que desceram a esta costa, e mortos alguns portugueses e escravos, porque são mui bárbaros, e toda a agente da terra lhes é odiosa. (GÂNDAVO, 1576, p. 140).

podemos considerar que alarves reescritura ${ }^{20}$ indios (aimorés) e é predicado por bárbaros. Ao se observar uma reescrituração, um procedimento de análise de que faço uso, é importante ver que parafraseamentos se podem fazer no caso. O termo que ficar na posição de predicado, na paráfrase feita, deve ser considerado o que determina o outro. Esse parafraseamento pode ser considerado também para relaçóes de articulação, nas quais tal relação predicativa pode ser encontrada. E aí deve-se considerar, da mesma maneira, que o termo que fica na posição predicativa determina o outro. No caso presente, a paráfrase envolvendo a reescrituraçáo de indios por alarves pode ser estes indios são alarves. Ou seja, alarve determina o sentido de indios. Por outro lado, alarve é reescriturado por elipse (vou marcar a elipse por $\mathrm{x}$ ) e assim se terá $x$ são bárbaros. E essa articulação predicativa projeta o predicado para o termo alarves e assim para indio, já que alarves determina este nome.

Mas se poderia considerar que se trata do predicado bárbaro atribuído a Aimorés, alarves é um reescrituração de indios aimorés, como vimos. Para avançar, vamos percorrer um outro caminho. Observemos como, na sequência a seguir, aparece uma relação entre indio e gentio. Há

\footnotetext{
${ }^{20}$ A reescrituração é, para mim, um procedimento enunciativo pelo qual se diz o que já se disse, e isso produz uma atribuição de sentido aos termos da reescrituração. Sobre isso, ver (GUIMARÃES, 2002, 2007a).
} 
um capítulo do livro de Gândavo que se chama Do Gentio (GÂNDAVO, 1576, p.121 e ss). Gentio aqui é reescriturado logo no primeiro parágrafo do capítulo por naturais dela (o dela reescritura por substituiçáo da terra). Uma outra reescrituração que se dá, logo no início do segundo parágrafo, é a de naturais da terra por estes indios. Assim, podemos observar que naturais da terra especifica gentio (os naturais da terra são gentios) e é reescriturado por sinonímia por indios. Podemos, entâo, dizer que indio tem o seguinte $\mathrm{DSD}^{21}$ :

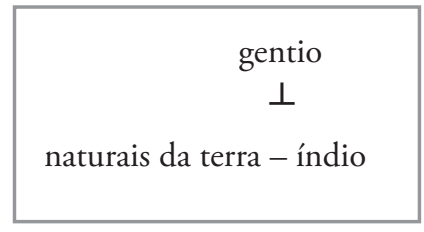

que se lê: há sinonímia entre naturais da terra e indio; gentio determina os termos dessa sinonímia.

Esta análise pode ser melhor especificada se consideramos que no segundo parágrafo do capítulo sobre o gentio encontramos uma reescrituração por expansão que atribui um conjunto de outras determinaçóes: "São desagradecidos, mui desumanos e cruéis, vingativos". Esses predicados estão diretamente relacionados a bárbaro, como se pode ver em

[no capítulo sobre guerra, que começa por estes indios] Mas afora esta pusilanimidade a que estão sujeitos, são muito atrevidos e tấo confiados em sua valentia, que não há forças de contrários tấo poderosas que os assombrem, nem que os façam desviar de suas bárbaras e vingativas tençóes (GÂNDAVO, 1576, p. 131).

Ou seja, indios, retomado por elipse na sequência, é predicado por bárbaros e vingativos, na medida em que o que se diz acima pode ser parafraseado, entre outras coisas, por os indios têm intençôes bárbaras e vingativas. Desse modo, podemos considerar que há um conjunto de determinaçôes que atribuem sentido a bárbaro, tais como: vingativo, desumanos, cruéis, desagradecidos, etc. Tem-se assim o seguinte DSD:

\footnotetext{
${ }^{21}$ O Domínio Semântica de Determinação (DSD) é a representação, a escrita da semântica, para a designação do nome.
} 


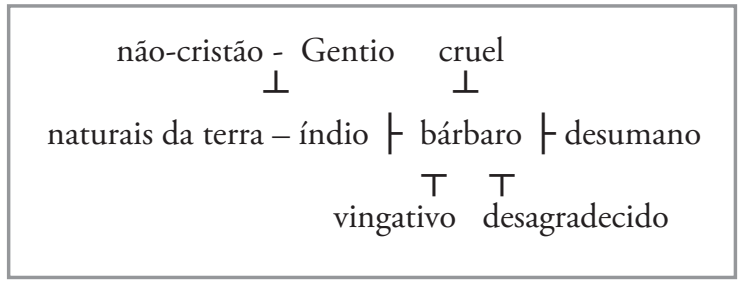

que se lê: não-cristão e gentio, sinônimos, determinam indio, sinônimo de naturais da terra; bárbaro também determina índio, sendo determinado por cruel, desumano, vingativo, desagradecido.

A sinonímia entre não-cristão e gentio pode ser estabelecida já que o sentido de gentio aparece no título do capítulo, como conhecido; mas, no próprio texto de Gândavo, encontramos: "Não adoram a coisa alguma, nem têm para si que há depois da morte glória para os bons, e pena para os maus" (GÂNDAVO, 1576, p. 122).

Essa reescrituração por expansão explicativa coloca a palavra gentio na conhecida história de sentido em que o gentio significa, o náo-cristão. Por isso, a determinação por sinonímia no DSD. E isso também está presente na medida em que alarve é uma reescrituração para índios aimorés. Essa questáo do sentido específico de alarve, veremos a seguir.

Se considerarmos um DSD para aimorés, teremos:

$$
\begin{gathered}
\text { gentio - não-cristão } \\
\perp \\
\text { índio }^{22} \\
\perp \\
\text { aimorés }- \text { alarves }
\end{gathered}
$$

A consideração da presença de alarve como elemento que atribui sentido a índio nesses textos, e no início da colonização do Brasil, coloca a questão da evangelizaçáo. Para tratar desse aspecto, é importante colocar uma questão de método central aqui. No domínio das ciências, um conhecimento produzido a partir de um domínio ou procedimento pode servir para outras análises. Mas não como uma simples transferência do conhecimento. Ao contrário, um certo conhecimento pode ser tomado como dado para outras análises, que devem apropriá-lo como fato a ser analisado. Aqui, no caso,

\footnotetext{
${ }^{22}$ Consideremos que indio aqui representa o DSD já estabelecido acima.
} 
vamos tomar o estabelecimento da etimologia da palavra alarve que servirá não como etimologia, mas como o registro de uma história de enunciaçôes, ou seja, vamos tomar a etimologia como um dado a ser visto como fato pelo método da semântica da enunciação. Tomemos entáo a etimologia, tal como está em Nascentes:

Alarve. Do ar. al-'arab "os árabes". Pelo modo de vida dos árabes, nômades e fora das cidades, passou a palavra a significar "bruto, grosseiro, sem maneiras", sentido ainda vivo na fraseologia: comer como um alarve. (NASCENTES, 1966, p. 24).

Esse dado pode ser tomado como a apresentação de uma história de acontecimentos de enunciação. Essa história pode ser assim apresentada:

$1^{\circ}$. Momento: [...] al-'arab [...] $=[\ldots]$ os árabes $[\ldots]$

$2^{\circ}$. Momento: $[\ldots]$ alarves $[\ldots]=[\ldots]$ os árabes $[\ldots]$

$3^{\circ}$. Momento: [...] alarves (por metáfora) $[\ldots]=[\ldots]$ rústicos $[\ldots]$

4․ Momento: $[\ldots]$ alarves $[\ldots]=[\ldots]$ rústicos, etc.

Os textos do século XVI considerados são enunciações de alarves já no sentido do quarto momento dessa história enunciativa. Uma história que na verdade é uma história de uma mudança na Língua Portuguesa. E a passagem pela metáfora continua a fazer sentido no funcionamento enunciativo da palavra.

Projetando isso sobre a questão do espaço de enunciação, essa história enunciativa mostra que, em um certo período, por todos conhecido, houve uma relação entre o romance e o árabe, e a palavra alarve é uma marca dessa relaçáo. Essa palavra, junto com outras que a ela podemos relacionar, até por seu modo de formaçáo no português, mostra-nos que, em algum momento, o espaço de enunciaçáo da península ibérica relacionou as línguas árabe e latim, depois o romance. Se essa relaçáo já é conhecida, interessa aqui o que essa história de enunciações coloca no funcionamento do sentido.

Se agora pensamos essa mesma história enunciativa para vermos como se dá a cena enunciativa e nela a designaçáo de índio, por exemplo, vemos como a Língua Portuguesa, mesmo depois que o espaço de enunciação se modifica na Península Ibérica, carrega a história dessa relação. E nessa história a palavra alarve, e sua enunciaçáo nesses textos sobre a colonização do Brasil, faz significar uma questão importante. Pela história da língua, traz para a cena uma correlaçáo de sentidos entre árabe e indio. Póe, no centro da questão do sentido de índio, naquele momento, o sentido de gentio, de 
não-cristão; a presença deste nome (alarve) produz assim sentidos muito específicos, pelo movimento do memorável do acontecimento. Inclusive porque ela aparece para opor índios bárbaros e muito bárbaros. Alarves aparece determinando aimorés. Determinação que se encontra em outro texto da época. No “Tratado Descritivo do Brasil em 1587”, encontramos:

E são estes Aimorés tão selvagens que, dos outros bárbaros, são havidos por mais que bárbaros, e alguns se tomaram já vivos em Porto Seguro e nos Ilheos, que se deixaram morrer de bravos sem quererem comer (SOUZA, 1587, p. 74).

[Estes aimorés] Não costumam estes alarves fazer roças, nem plantar nenhuns mantimentos, mantêm-se de frutas silvestres e da caça que matam, a qual comem crua ou mal assada, quanto têm fogo [...]. (SOUZA, 1587, p. 75).

$\mathrm{Na}$ presença desta palavra (alarve), aparece uma questáo importante: esse nome é produzido a partir de uma cena em Língua Portuguesa (no espaço de enunciação em que funcionava a Língua Portuguesa naquele momento), na qual os árabes são chamados alarves (uma palavra vinda do árabe) e é também numa cena em português que se dá a metáfora. E é essa distância que a cena em português traz que abre o caminho da metáfora e da crítica àqueles que são nomeados, por uma palavra inicialmente de sua língua, a partir de outro lugar.

\section{Consideraçóes Finais}

Um primeiro aspecto importante é que a análise que fizemos permite dizer que, num primeiro momento da história da colonização portuguesa, o espaço de enunciação tem uma configuraçáo que não consideramos na síntese que fizemos em 2005. Tal como vimos na análise feita, o espaço de enunciação específico do início do século XVI, mesmo que tomado globalmente no Brasil de então, não inclui o holandês. Desse modo, podemos considerar que a primeira configuração do espaço de enunciação nas terras do brasil é algo que precede o que consideramos como primeiro momento na síntese acima referida.

Além desse ganho descritivo, que pode ser melhor configurado em pesquisas específicas, podemos dizer que as análises nos permitiram, ao retomar o conceito de espaço de enunciação - considerando como ponto de partida relaçóes entre enunciaçóes que os documentos nos permitiram analisar -, deixar claro como a caracterização do embate próprio do espaço 
de enunciação é político e não algo simplesmente externo que se correlaciona com o linguístico. $\mathrm{O}$ embate foi aqui caracterizado a partir do litígio de enunciações, pelas quais se observa que uma nomeação feita é preterida por uma outra enunciação que renomeia. Mesmo assim, a língua preterida continua afirmando seu pertencimento ao espaço de enunciação.

Por outro lado, a análise mais detalhada da cena enunciativa, tomada como ponto de partida, mostra como seu funcionamento está articulado ao espaço de enunciaçáo. O que está diretamente ligado com os processos de agenciamento próprios do acontecimento de enunciação. É mesmo possível ver como a análise da cena sustenta de modo claro o que consideramos como o conflito político do espaço de enunciação.

O acontecimento de enunciação (que se dá no espaço de enunciação) afeta esse espaço pelo agenciamento em Locutor, locutor-x e enunciador que afeta o falante. Este náo fala como falante, mas como Locutor e locutor-x, e esta "distância" produz mudança. Movimenta-se uma história de sentidos, não só sistemas de regularidades (línguas), e projetamse futuros de sentido antes inexistentes. Por exemplo, enuncia-se jenipapo num acontecimento e isso projeta um novo futuro no qual jenipapo estará novamente. Isso, entre outras coisas, muda as línguas.

E ao fazer uma análise de um outro aspecto do funcionamento enunciativo, o da designação, ou seja, pela observação de como a designação se constrói no acontecimento (em cenas enunciativas), pode-se ver como, no acontecimento, significa sempre uma história de enunciações.

É possível considerar como aquilo que se constitui em certos espaços de enunciação pode se colocar na língua e ir para outros espaços de enunciação, podendo tomar outros caminhos, significar em outros acontecimentos.

A análise da designação, por outro lado, traz para a discussão a significaçáo de valores (bárbaro, cruel, alarve, etc), que incluem ou excluem ${ }^{23}$. Nessa medida, a análise feita se localiza numa história de designaçóes que marca a Língua Portuguesa, que assim aparece como a língua com a qual se diz legitimamente a colônia.

Se estabelecemos o espaço de enunciação, tal como fizemos, e depois analisamos as cenas e a designação, vemos como tudo, no conjunto, sustenta e especifica o espaço de enunciação e tira dele elementos da produção dos sentidos no acontecimento enunciativo.

\footnotetext{
${ }^{23}$ Este tipo de questão aparece em discussões como as de Kosselleck (1979), Starobinsky (1989), Montaigne (1595), Orlandi (1990), Guimarães (2012, 2004, 2006, 2007b, 2007c), ou ainda, de Rancière $(1992,1994)$.
} 


\section{Referências}

GÂNDAVO, P. M. de. História da Província Santa cruz. São Paulo: Hedra, 2008.

GUIMARÃES, E. Texto e Argumentação. Campinas: Pontes, 1987.

Semântica do Acontecimento. Campinas: Pontes, 2002.

Civilização na Linguística Brasileira no século XX. Matraga. Rio de Janeiro, n.16, p. 89-104, 2004.

. A Língua Portuguesa no Brasil. Ciência e Cultura, 57, n. 2, São Paulo: SBPC, p. 24-28, 2005.

- Espaço de enunciação e política de línguas no Brasil. In: OLIVEIRA, S. E. de e SANTOS, J. F. (Orgs.). Mosaico de linguagens. Campinas: Pontes/CELLIP, 2006.

- Domínio Semântico de Determinação. A Palavra: Forma e Sentido. Campinas: RG/Pontes, 2007a.

. The Concept of Civilization in Historic Brazilian Linguistics. In: Kibee, D. (Org.). History of Linguistics 2005. Amsterdam: Benjamins, 2007 b.

Política de línguas na lingüística brasileira. In: ORLANDI, E.P. (org.). Política lingüística no Brasil. Campinas: Pontes, 2007c.

Análise de texto: um Estudo Enunciativo. Conferência na 60a . Reuniáo Anual da SBPC, Campinas: Unicamp, 2008.

Análise de Texto. Procedimentos, análises, Ensino. São Paulo: Hucitec, 2013.

. Sujeito, Civilização e Cultura: uma História de Palavras e Conceitos. In: MALUF-SOUZA, O; SILVA, V; ALMEIDA, E. de; BISINOTO, L.S.J. (org.). Discurso Sujeito e Memória. Campinas: Pontes, 2012.

O Diário de Navegação de Pero Lopes de Souza. Um Percurso e Política de Nomes Próprios. Conferência, II Encontro Semântica e Acontecimento. Campinas: Unicamp, 2013. 
. Contatos na Costa da Terra Do Brasil. A Inexistência das Línguas.

Linguagem, Sociedade, Políticas. Programa de Pós-graduação em Ciências da Linguagem. Pouso Alegre: Univás, 2014.

KOSSELLECK, R. Futuro Passado. Rio de Janeiro: Contraponto/Editora da PUCRio, 2006.

MONTAIGNE, M. de. Ensaios. Uma Seleção. São Paulo: Penguin/ Companhia das Letras, 2010.

ORLANDI, E. P. A Linguagem e seu Funcionamento. Campinas: Pontes, 1987.

. Terra à Vista. São Paulo: Cortez/Editora da Unicamp, 1990.

. As Formas do Silêncio. Campinas: Editora da Unicamp, 1992.

NASCENTES, A. Dicionário Etimológico Resumido. Rio de Janeiro: INL, 1966.

RANCIÈRE, J. Os Nomes da História. São Paulo: Educ/Pontes, 1994. . La mésentente. Paris: Galilée, 1995.

SOUZA, P. L. Diario da Navegaçáo da Armada que foi à Terra do Brasil em 1530 Sob a Capitania-mor de Martim Affonso de Souza (15301532). Lisboa: Typografia da Sociedade Propagadora dos Conhecimentos Uteis, 1839.

SOUZA, G. S. de. Tratado Descritivo do Brasil em 1587. São Paulo: Hedra, 2010.

STAROBINSKY, J. As Máscaras da Civilizaçáo. São Paulo: Companhia das Letras, 2001. 